資 料

\title{
末燒成窯業素地の膨脹並に收縮測定
}

\author{
加 藤 左 織
}

(Von Prof. Dr. W. Steger, Ber. Deut. Keram. Gesell., 1938, 19, 1, 2〜22)

(1937 年 10 月 26 日, フライブルグ市に於ける獨逸窯業協會 18 回大會に於ける講演)

(ベルリン國立磁器製造所化學工業研究所研究報告)

燒成時の䈘業原料又は素地の變形に就いては種々なる方法で研究 し得られるが最も多く用ひられる方法は種々の溫度で燒いた物の燒 成收縮, 氣孔率及び比重を測定する事である.

燒成收縮の測定は大抵正しく成形された物例へば平板に標しを付 け，其本板を實驗室爐又は工業用爐にて燒成し冷却後の其標しの距 離の變化を測定する. 收縮測定及び氣孔率測定により粘土又は素地 の狀態を明かにするためには出來る文細かい、溫度間隔 (大抵 $104{ }^{\circ} \mathrm{C}$ 間隔，稀には $50^{\circ} \mathrm{C}$ 間隔)・で行はねばならない。

特別なる場合には收縮の測定は叉他の種々の方法で行はれる. 色 色の研究者達郎ち Braesco 1913, Satoh 1921, Houldsworth u. Cobb 1923, Moore 1925, Hirsch 1927, Miehr-Kratzert-Immke 1927, Bartsch 1929 等が行つたのは(1)カオリン及び粘土で作られ た測定體は裝置中で連續的に加熱されて熱膨脹を測定し 熱收縮は脹 膨測定操作後に逐行して圖表で示した． R. Schwairz u. W. Klös に依れば(2) カオリンを $20^{\circ} \sim 1000^{\circ} \mathrm{C}$ の範圍內で加熱した時起る經 過を熱膨脹測定の裝置で檢べ侗亦カオリン，長石，石英及び攀土よ り作つた未燒成素地に就いても測定した。（3）種々の反應を熱膨脹 測定方法を用ひて知る目的の下に以上と同じ樣な廣大な研究を $\mathrm{H}$. Salmang u. A. Rittgen が行ひ發表してるる. 此兩氏は多數の粘土 の生の狀態のものと $1000^{\circ} \mathrm{C}$ に燒成した物に就いて行つてるる. T. Yoshioka, T. Horie u. J. Karashima の諸氏は (4)粘土, 粘土一 石英, 粘土一石長及び粘土一石英一長石よりなる素地並びに日本 磁器に就いて同樣な測定を $1300^{\circ} \mathrm{C}$ 汽加熱して行つた. 倘高溫度迄 $\left(1500^{\circ} \mathrm{C}\right.$ 迄) 行つたのは (5) C. W. Parmelee u. J. H. Chesters で此兩氏は高㴘度に於ける石英よりクリストバライトの生成及び未 燒成素地よりスピネルの生成を研究するのに此膨脹收縮測定を利用 した.

今日迄報告されてるる研究は大抵 $1200^{\circ} \mathrm{C}$ 迄時として $14 \mathrm{C} 0^{\circ} \mathrm{C}$ 迄 で行はれてるて, カオリン, 粘土及び筧業素地の膨脹收縮曲線が 示され燒成時に原料及び素地中に起る種々の變化を證明してるる. 此等の測定裝置は皆似た樣な種類の物で燒成された素地の熱膨脹測 定は此較法が用ひられてるる. $1000^{\circ} \mathrm{C}$ 以上の石英硝子が使用され得 る溫度以上迄の測定には石英硝子の代りにベルリン國立磁器製造所 のマルクワント (Marquardt) 素地を管狀又は棒狀にしたものが用 ひられる. 此の高攀土質の高溫度燒成素地は $1400^{\circ} \mathrm{C}$ 迄は均等な膨 脹を示す, W. M. Cohn (6) は其故に比較的高溫度の熱膨脹の測定 裝置に用ふる事を推賞してるる. 第 1 圖は此のマルクワット素地と 石英硝子の熱膨脹の比較圖であつて, マルクワット素地は不英硝子 の大約 8 倍の膨脹安示す。
第 1 圖 マルクワット素地及び石英确子の本均 線膨脹率 $\left(20^{\circ} \mathrm{C}\right.$ に於ける最初の長さに對する\%)

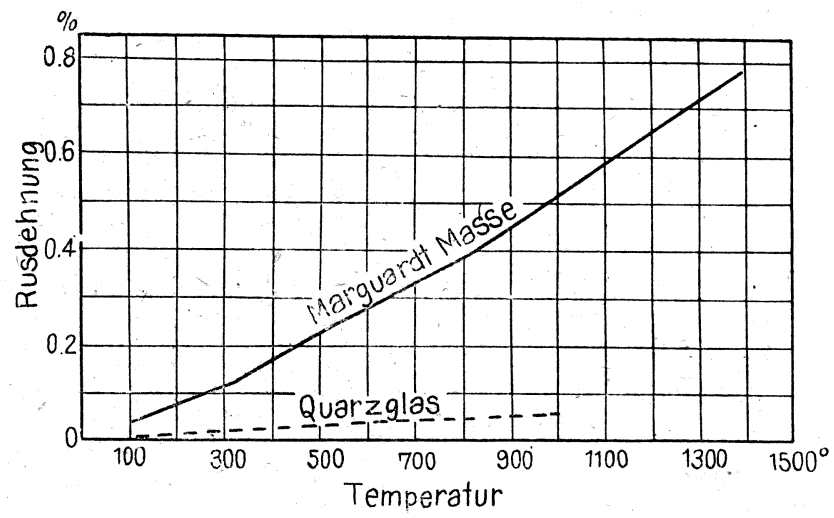

新しい裝置の一つを示すと第 2 圖の樣である郎ち輪緣 1 を有する パイロメーター管がある, それは長さ $500 \mathrm{~mm}$ 內徑 $11 \mathrm{~mm}$ 外徑 $17 \mathrm{~mm}$ の大きさでマルクワット素地で出來てるて其內部の下には測
第 2 圖、未燒成窯業原料及ど素地の 膨脹收縮測定裝置

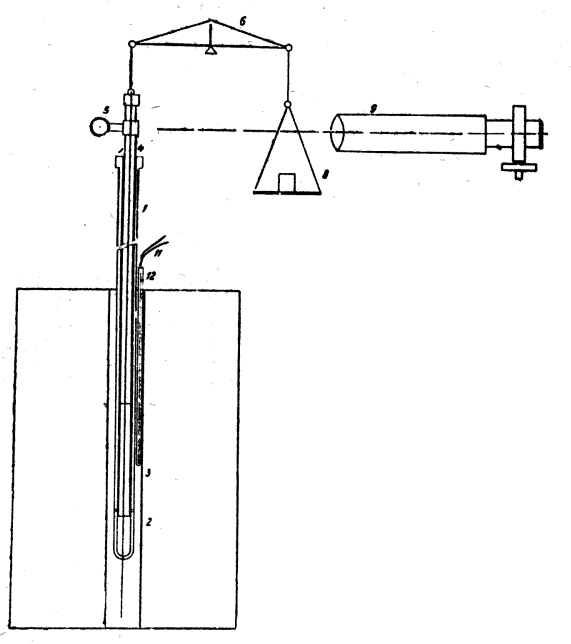

定試驗體を載せる やはりマルクワ。 ト素地で作られた 栓 2 が入つてる る. 試驗體 3 は長 さ $100 \mathrm{~mm}$ 直徑 11) $\mathrm{mm}$ の物を使用 する. 試驗體の上 端には長さ 400 $\mathrm{mm}$ 直徑 $8 \mathrm{~mm}$ の マルクワット素地 製の棒が立つてる て其棒が試驗體の 長さの變化を十字 絲標 5 に移す役目 をする. 此棒は科
り 6 の一方の腕に吊されてるる. 電氣爐 7 は白金簿撩付のーリュー 不爐で長さ $300 \mathrm{~mm}$ で $30 \mathrm{~mm}$ の加熱管直徑を有し下端は閉ぢてる る. 試驗體の下端に近い載臺 2 の上の場所には管 1 の壁に二つの孔 が穿たれてるるが加熱された空氣は此孔を通つて試驗體に達し測定 中に有機物等は燃燒し去る。 
秤り 6 の皿 8 上に重量を載せて試驗體 3 に加はる荷重を任意に變 化し得るが其操作は測定時には無荷重になる樣にして只讀夕取る極 〈短時間だけ荷重が增大する，乙かし其全荷重も10 gr 位で直徑 $10 \mathrm{~mm}$ の試驗體では比荷重值は約 $1.3 \mathrm{~g} / \mathrm{cm}^{2}$ である.

此の十字絲 5 の動きは望遠㙷微鏡 9 で測るが此の望遠鏡は焦點距 離 $10 \mathrm{~cm}$ の對物鏡と $10 \times$ の螺旋マイクロメーター付眼鏡を供へ 1 目盛は $0.02 \mathrm{~mm}$ の長さの變化に相當する.

溫度は白金一白金口ヂウム熱電對 11 により測られるが其熱電 對は下端が閉ぢた保護管 12 中に大れられてるる。其下端は丁度試 剑體の中心に來る樣に保たれる。溫度上昇は全測定中均等に每分 5 $\sim 6^{\circ} \mathrm{C}$ 宛とし讀みは $20^{\circ} \mathrm{C}$ 間隔に行つた。

$1200^{\circ} \mathrm{C}$ 以上の測定に對しては $6.5 \mathrm{~cm}$ の直徑を有する電氣炭素粒 抵抗爐を使用し其爐の强い熱放射より裝置を保護するため管1の長 さを $850 \mathrm{~mm}$ 以上としマルクワット素地より成る棒 4 の長さを 750 $\mathrm{mm}$ 以上飞した.

マイクロメーターの讀みは百分率に換算しそれにマルクワット素 地の熱膨脹の百分率換算值を加へて $20^{\circ} \mathrm{C}$ の最初の長さに對する百 分率值て膨脤收縮の絕對値を出した。

次に測定結果を示すが其は 2 種のカオリン，1 種の可塑性に富む 确器粘土, 1 種の頁岩粘土, チェットリッッカオリンと種々の脱粘 物質との混合物及び 3 種の筧業製品素地郎ち石灰陶器, 混合陶器, 硬質磁器等である.原料物質は次の樣である, 即ちチェットリッツカオ リン，水筂されたケムリッツエルカオリン Oka，海岸より座する粘 土,ザール產頁岩粘土，ニューロード產の燒成頁岩粘土, ホーェン ボゥカ產砂, ノルウェ一產長石 (Mikroklin), 非常飞純粹で殆ど鐵分 の無いスェーデン產の雲母(加里雲母)，ブンヂィーデル產の方解石， フランケンシュタイン產のマグネサイト，ゲーパルスグリューン產 の滑石，產地不詳の螢石である。測定用棒は長さ $10 \mathrm{~mm}$ で直徑 $10 \mathrm{~mm}$ として塺搾成形され $105 \sim 110^{\circ} \mathrm{C}$ で乾燥され測定する迄デシ ケーター中で保存された。

未燒成のチェットリッツカオリンの膨脹收縮曲線は第 3 圖に示し た. 其の上昇膨脹線中には何の變化點も無く滑かに昇り $560^{\circ} \mathrm{C}$ で頂 點に達する. $560^{\circ} \mathrm{C}$ より $840^{\circ} \mathrm{C}$ 迄の降下曲線中には變化點が存在 し特に $740^{\circ} \mathrm{C}$ のものが眼立つてるる. $880^{\circ} \mathrm{C}$ の點は銳い彎曲點をな し其より曲線は $560^{\circ} \sim 840^{\circ} \mathrm{C}$ の時より急激に降下する. $980^{\circ} \mathrm{C}$ では 第三の彎曲點を示し曲線は再び第四の彎曲點の $1100^{\circ} \mathrm{C}$ 迄は比較的

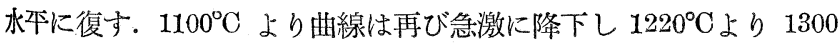

第 3 圖 チェットリッツカオリンの膨脹收縮曲線

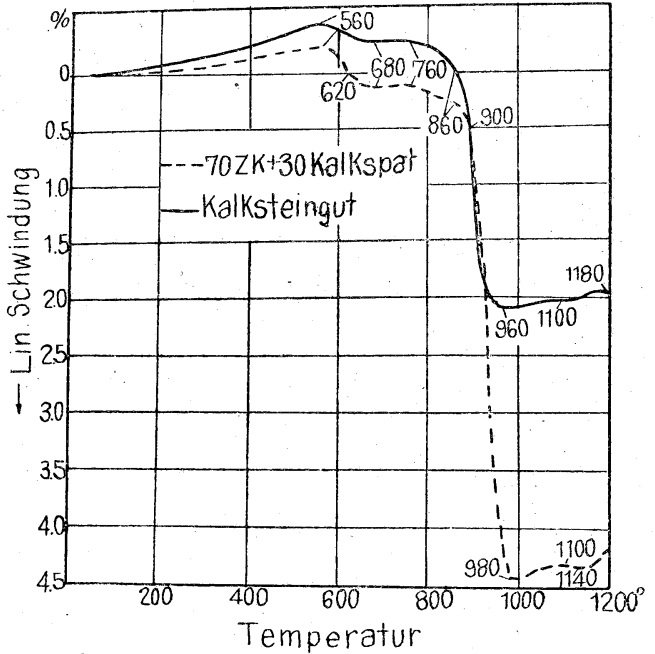

${ }^{\circ} \mathrm{C}$ 迄はや」降下度が緩かとなり $1300^{\circ}$ より $1400^{\circ} \mathrm{C}$ 迄は更に降下 する.

更に他のカオリン郎ち約 $90 \%$ の粘土物質を有するケムリッチェ ルカオリンオカ (Kemmlitzer Kaolin Oka) (第 4 圖)の場合は前と 似た樣な狀態を示すが同一の膨脹收縮曲線圖 ではない。曲線の頂點 は $520^{\circ} \mathrm{C}$ に於て已に達し膨脹を示す上昇線には $820^{\circ} \mathrm{C}$ に最初の彎 曲點が存在すチェットリッッカオリンの場合は $840^{\circ} \mathrm{C}$ にては未だ 曲線は水平に走つて居たのに對し此のカオリンは已に $820 \mathrm{C} よ り$ 曲 線が低下し始める, 又チェットリッッカオリンでは $880^{\circ} \mathrm{C}$ で特徽あ る彎曲點を示したが此では $900^{\circ} \mathrm{C}$ に存在する.曲線を辿つて行くと 次に $980^{\circ} \mathrm{C}$ で銃い明膫な彎曲點が岕り此より曲線はや小水本となり $1100^{\circ} \mathrm{C}$ で下方に彎曲移行する。

$$
\text { 第 } 4 \text { 圖 ケムリッチェルカオリン Oka の }
$$
膨脹收縮曲線

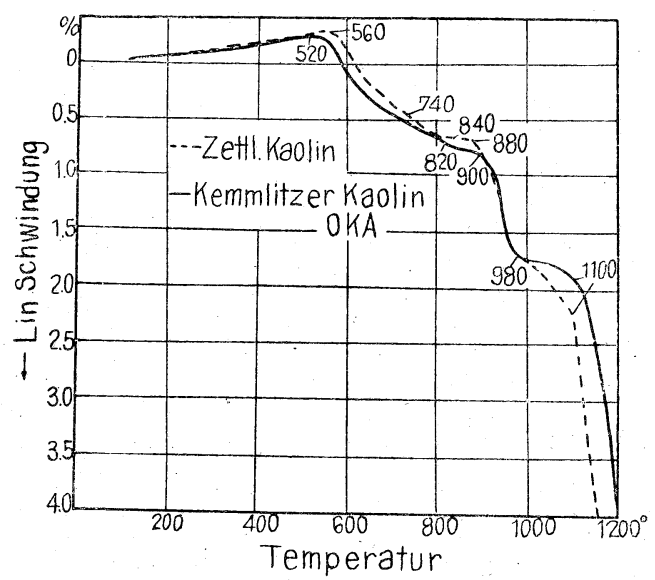

$1200^{\circ} \mathrm{C}$ に於ける收縮を見るにチュットリッツカオリンでは $6.5 \%$ であるが此ケムリッッエルカオリンでは僅に $49 \%$ に過ぎない。

粘士質物の分解過程を檢討せんとした多數の研究者の報告を見る にカオリンの膨脹收縮曲線よりカオリンの分解溫度及び新らしき化 合物の形成罝度を求め得る，しかし約 $400^{\circ} \mathrm{C}$ で起るカオリンよりの 脫水開始溫度は膨脹收縮曲線中には現はれない，それは加熱速度が 比較的早いからである. $560^{\circ} \mathrm{C}$ ではカオリンは充分分解し粒子と粒 子とが互ひに接近し收縮して來る. $880 \sim 900^{\circ} \mathrm{C}$ では珪酸アルミニウ ムと $\gamma-\mathrm{Al}_{2} \mathrm{O}_{3}$ と力゙同時に形成し始め $1100^{\circ} \mathrm{C}$ にては $\gamma-\mathrm{Al}_{2} \mathrm{O}_{3}$ の生 成範圍が終り珪酸アルミニウムの形成が此溫度より甚だしく堾大す る. $1200^{\circ} \mathrm{C}$ 以上の溫度では $1220^{\circ} \sim 1300^{\circ} \mathrm{C}$ の間で收縮度が衰へる 事よりクリストバライトが著しく形成する事が制る.

粘性炻器粘土即ち海濱產粘土（第 5 圖）の膨脹收縮曲線ては $160^{\circ}$, $240^{\circ}$, 及び $320^{\circ} \mathrm{C}$ で變化性を示してるる, 而して其の頂墨は $540^{\circ} \mathrm{C}$ に存在する. $540^{\circ} \sim 860^{\circ} \mathrm{C}$ の間ではチェトリッッカオリンの場合と 似た樣な變化狀態を示し曲線降下は殆ど均等に $860^{\circ} \mathrm{C}$ 迄走つてみ る. $860^{\circ} \mathrm{C}$ よりは曲線は䇿かな彎曲を以て下方に降る. $960^{\circ} \sim 1040^{\circ} \mathrm{C}$ では曲線は更に二つの彎曲點を有するが $1100^{\circ} \mathrm{C}$ では彎曲點は殆ど 認められない，斯の如く此粘土は多量の融劑を含有するに拘らずカ オリン曲線の最も重要なる彎曲點は此粘土の曲線にも現はれ從つて 上記のカォリン中の粘土質物の轉移は此の Seeton にも存在する事 が制る。

未臸成頁岩粘土 (第 6 圖)の膨脹收縮曲線を見るに已に述べたカオ リンの場合の彎曲墨の外に新たに顯著な鸞曲點が認められる。先づ $100^{\circ} \mathrm{C}$ 迄强大なる膨脹をなした後 $160^{\circ} \mathrm{C}$ 迄收縮する. $240^{\circ} \mathrm{C}$ より再 び徐々に膨脹し $440^{\circ} \mathrm{C}$ に膨脹が止まり $440^{\circ} \sim 500^{\circ} \mathrm{C}$ 間は水平に走 
第 5 圖 ゼー粘土の膨脹收縮曲線

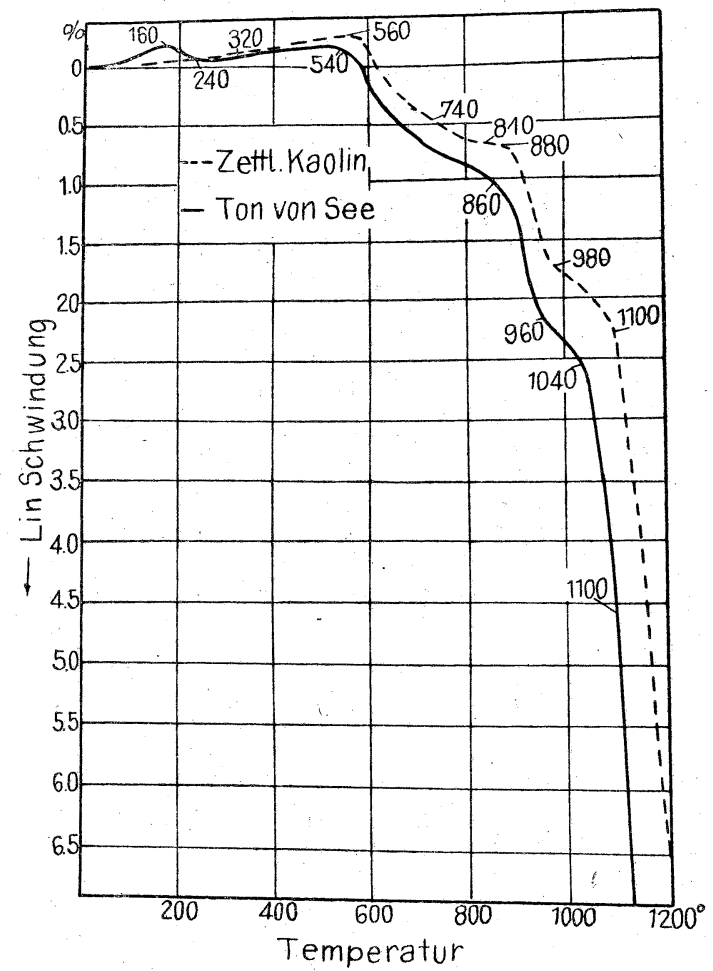

る. $500^{\circ} \mathrm{C}$ にて初めて强い收縮が始まるが其收縮は $720^{\circ} \sim 740^{\circ} \mathrm{C}$ 間 で特に大であつて $20^{\circ} \mathrm{C}$ の此短い、溫度範圍に於て $1 \%$ 餘も收縮す る. $880^{\circ} \mathrm{C}$ と $960^{\circ} \mathrm{C}$ ではカオリンの場合と同樣なる二つの彎曲點を 示すが次の彎曲點はカオリンでは $1100^{\circ} \mathrm{C}$ で現はれたが此粘土では $40^{\circ} \mathrm{C}$ 高い $1140^{\circ} \mathrm{C}$ の所に認められる.

此處で注意すべきは $500^{\circ} \sim 880^{\circ} \mathrm{C}$ 間の收縮曲線の移行狀態である. 郎ちカオリンでは極く弱く現はれた $740{ }^{\circ} \mathrm{C}$ の彎曲點が此頁岩粘士で は明膫な彎曲點を示し此處で $720^{\circ} \sim 740^{\circ} \mathrm{C}$ 間の急激な收縮が終つて るる，それで此の變化を詳細に知るための試驗を行はなくとも此の 收縮曲線より此 $740^{\circ} \mathrm{C}$ で恐らくカオリンの分解生成物の形成が停止

第 6 圖 生頁岩粘土の膨脤收縮曲線

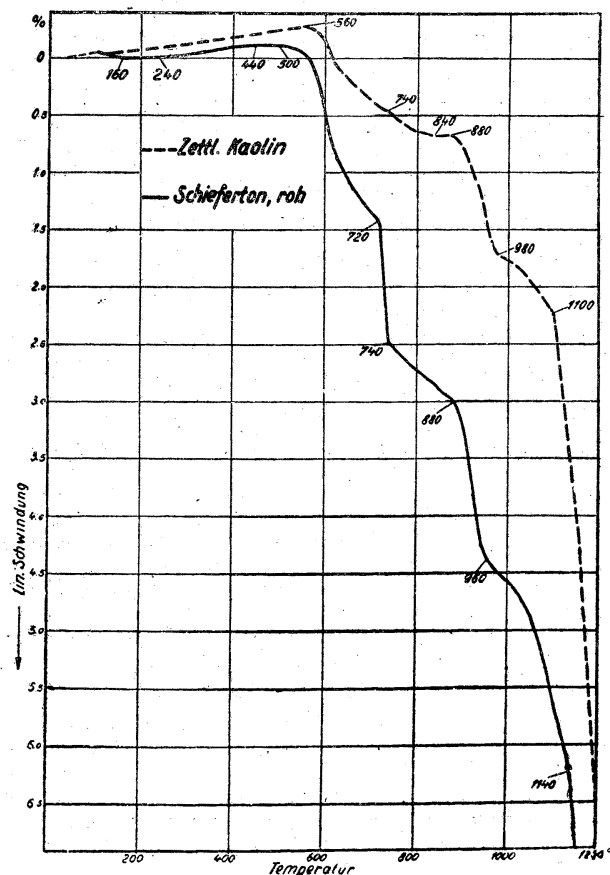

するか又は他の形の粘土質物が形成する事が推察される。

膨脹收縮曲線の形に對する脫粘劑の作用を知るためにチェットリ， ツカオリンと種々の不粘性物質とを 70:30 の重量比に混合した素 地に就いて研究した。脫粘性物質の粒子敩組成を均一に保つために カオリンと混合する前に Din-Sieb (規格穊) Nr。0.088 を通して比 較的大なる粒子を除く、脱性物質がカオリン中で不活性狀態で存在 するか又はカオリンと化學的に反應するかによつて收縮曲線はチ ェッ トリッッカオリンと似た樣な狀態を示すか又は一定の新しい曲線形 を示す岁のである。

生のチェットリッツカオリン $70 \%$ と SK 15 番で堯成した同粘 土 $30 \%$ の混合物の $1200^{\circ} \mathrm{C}$ の焅成收縮は生カオリンで $6.5 \%$ でるの が $48 \%$ に低下するが最初の $540^{\circ} \mathrm{C}$ 迄の上昇曲線は朌粘劑を含まない カオリンのそれと一致してるる. $540^{\circ} \mathrm{C}$ より溫度上昇すれば $30 \%$ の 筑成カオリンの影響を受けて生カオリンのみの物より收縮が減少す る. 特に $540^{\circ} \sim 880^{\circ} \mathrm{C}$ 間と $980 \sim 1100^{\circ} \mathrm{C}$ 間にて兩者の收縮度に差 が生ずる．而して桼成カオリンを含む粘土の收縮曲線では $740^{\circ} \mathrm{C}$, $840^{\circ} \mathrm{C} ８ 80^{\circ} \mathrm{C}$ で明膫に認められる彎曲點が存在するが $980^{\circ} \mathrm{C}$, 及び $1100^{\circ} \mathrm{C}$ の彎曲點は餘り明嘹でない. $1040^{\circ} \mathrm{C}$ に於ては明炕新しい督 曲點が現はれてるるもので此は媴成したカオリンを含むため珪酸了 ルミニウムの生成に關係あるものと思はれる。

第 7 圖 $70 \%$ チェットリッツカオリン $+35 \%$ 燒成 (SK 15) チェットリッツカオリ シの膨脹收縮曲線

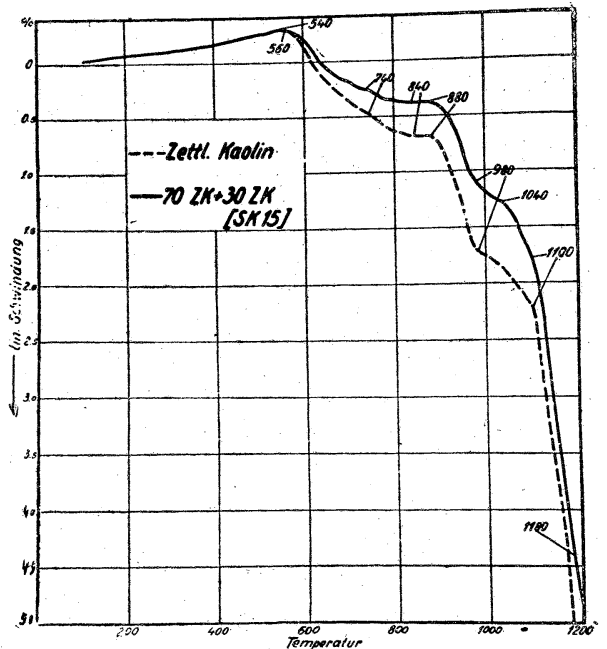

ノイロード産頁岩粒士 (Neuroder Schieferton) の燒成物を $30 \%$ 爻チェットリッツカオリンに加へた特の收縮は前の燒成チェットクッ ッカオリンを加へた時と餘り大差がない（第 8 圖）燒成ノイロード 粘土を加へた時の收縮度の減少はやはり $560^{\circ} \sim 880^{\circ} \mathrm{C}$ 間と $980^{\circ} \approx$ $1100^{\circ} \mathrm{C}$ 間で特に著しく起るがそれより高溫では餘り變らないで新た に減少を見る事がない。

チェットリッツカオリンに砂 (30\%)を加へて脫粘した時の曲線は第 9 圖に見る如く最初の膨脹曲線がカオリンの久の場合より上昇して るて $560^{\circ} \mathrm{C}$ で $0.12 \%$ 丈高い. $560^{\circ} \mathrm{C}$ より收縮し始めると最初の彎 曲點は $620^{\circ} \mathrm{C} \cdot て ゙$ 起る. 其他の變化は脫粘されないカオリンのみの場 合と殆ど同溫度で起つてるる. 此のホーエンボッカ砂の添加のため 起る收縮度の減少は $560^{\circ} \mathrm{C} \sim 900^{\circ} \mathrm{C}$ 間々 $980^{\circ} \sim 1080^{\circ} \mathrm{C}$ 間の二つの範 圍で著しい佮又其他 $1180^{\circ} \mathrm{C}$ 以上でも收縮度が減少し $1180^{\circ} \mathrm{C}$ で曲 線はや〉上方に折れ曲つてるる。

長石を $30 \%$ 文カオリンに混合した場合は第 10 圖に見る樣にや はり曲線は $560^{\circ} \mathrm{C}$ 迄膨脹するが收縮線に於ては $640^{\circ} \mathrm{C}$ で最初に統 
第 8 圖 $70 \%$ チェットリッツカオリン $+30 \%$ ノイ ロード產粘土（燒成物）の膨脹收縮線

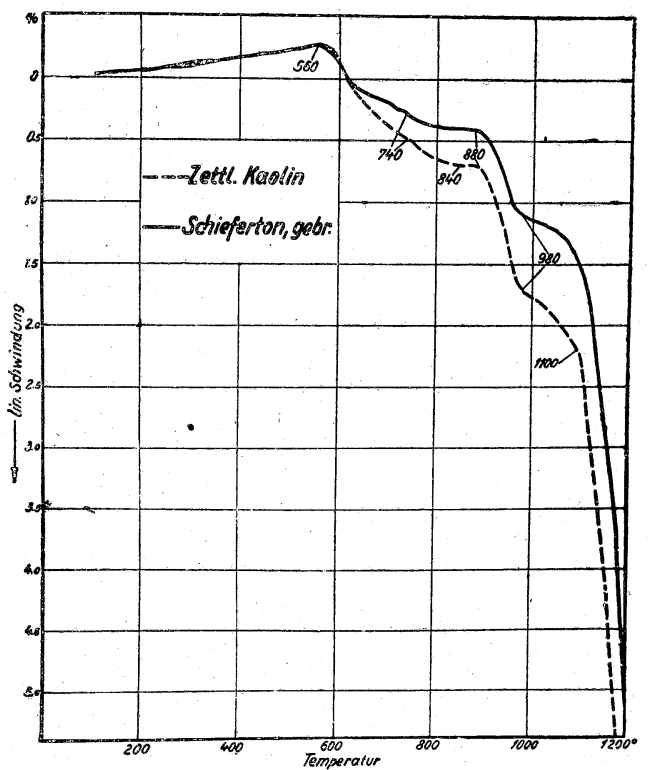

第 9 圖 $70 \%$ チェットリッツカオリン $+30 \%$ ホーエンボッカ砂の膨脹收縮曲線

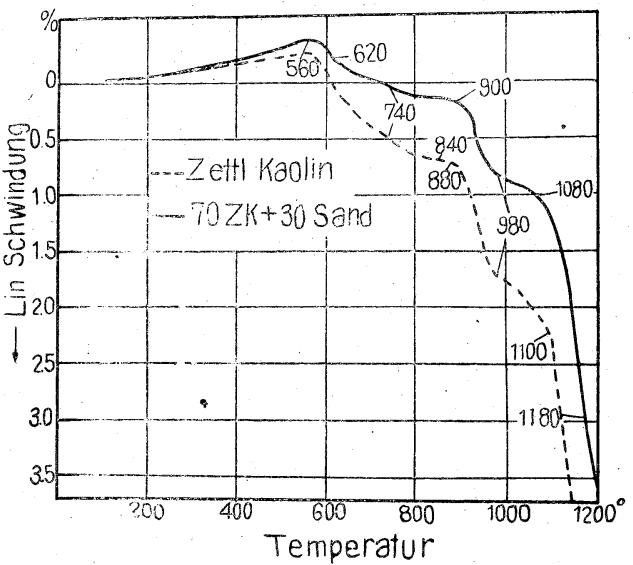

化性を示し, $640^{\circ} \sim 820^{\circ} \mathrm{C}$ 間で收縮度は幾分減少する, 更に $820^{\circ}$ $900^{\circ} \mathrm{C}$ では逆に僅に膨脹を示す. $900^{\circ} \mathrm{C}$ よりはカオリンのみの場合 々同樣に曲線は降下し始め收縮を起す。少くの如く長石は $1100^{\circ} \mathrm{C}$ 迄 はカオリンの收縮を隇少せしめる作用をなすが $1120^{\circ} \mathrm{C}$ 以上になる と明に長石がカオリンに對し愹媒作用をなす事が知られ逆にカオリ ンの收縮を增大せしめ $1200^{\circ} \mathrm{C}$ で其收縮率は $8.1 \%$ に達する.

白雲母 (加里雲母) (第 11 圖)を $30 \%$ 加へた時のチェットリッッ カオリンの膨脹收縮曲線に於ては $1100^{\circ} \mathrm{C}$ 迄に著しい特徵を示して るる。 上弹膨脹曲線中にも $280^{\circ} \mathrm{C}$ で變化が認められ其膨脹性もカオ リンのみの場合より大であつて $560^{\circ} \mathrm{C} て ゙ ~ 0.43 \%$ の膨脹率を示す.

$560^{\circ} \mathrm{C}$ で收縮を開始したる後素地は $620^{\circ} \mathrm{C} よ り$ 膨脹し $760^{\circ} \mathrm{C}$ を經 て $880^{\circ} \mathrm{C}$ に至る.而して最初の膨脹は非常に劇しく現はれる. $960^{\circ} \mathrm{C}$ ではカォリン及び粘土でせに知られた曲線屈曲點が存在す. $1020^{\circ} \mathrm{C}$ で始めて特有の强い收縮が始まり． $1100^{\circ} \mathrm{C}$ より雲母の熔媒作用が現 はれて來る. 化學的に結合したる水分は $700^{\circ} \mathrm{C}$ 以上にて初めて雲母 加出る故に [K Steinbrecher (7) u. A. Zwetsch (8)] $620^{\circ} \mathrm{C}$ 以 上の膨脹は雲母の脫粘劑としての作用によるの久ならず素地中に大 つてるる雲母部分自體の物理的作用をも意味する.ものである. $760^{\circ} \mathrm{C}$ に於ける曲線の彎曲は已に水分が雲母より脫出した事を物語る。
第 10 圖 70\% チェットリッツカオリン $+30 \%$ 長石素地の膨脹收縮曲線

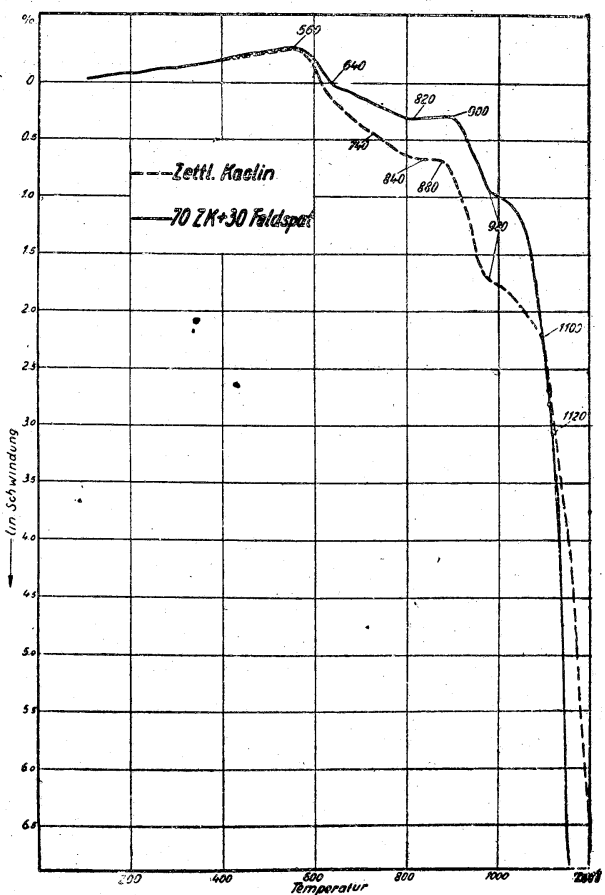

$880^{\circ} \mathrm{C}$ では次の轉移が同時に起る，郎ち雲母の分解と珪酸アルミニ ウム及び， $\gamma-\mathrm{Al}_{2} \mathrm{O}_{3}$ の生成開始である.A. Zwetsch (8) の說によれ ば $1020^{\circ} \mathrm{C}$ では $\gamma-\mathrm{Al}_{2} \mathrm{O}_{3}, \alpha-\mathrm{Al}_{2} \mathrm{O}_{3}$ 及び白榴石 (Leuzit) が生成する らしい. $960^{\circ} \mathrm{C}$ の彎曲點は $\gamma-\mathrm{Al}_{2} \mathrm{O}_{3}$ の强い生成を意味するるので燒 かないカオリンでも同溫度でそれは認められる。

カオリンに劇しく作用し且つ低溫度で作用する融劑はす方解石であ るが其れを $30 \%$ 丈けチェットリッッカオリンに添加した素地の收 縮曲線は第 12 圖に示す如く他のアルカりを含有する融劑, 長石及

第 11 圖 70\% チェツトリッツカオリン $+30 \%$ 白雲母の膨脹收縮曲線

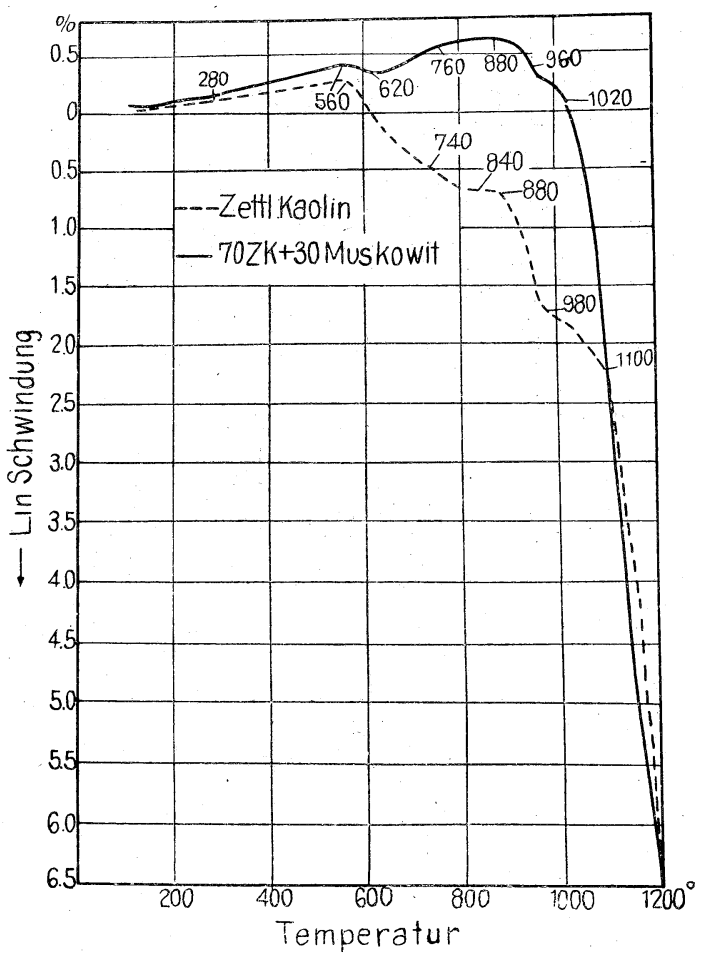


び雲母と非常に異つてるる. $560^{\circ} \mathrm{C}$ 、で膨脹が終りカオリンの場合と 同樣に $620^{\circ} \mathrm{C}$ 迄僅に收縮した後收縮が停止して $680^{\circ} \mathrm{C}$ を經て $760^{\circ} \mathrm{C}$ 迄曲線は水本に走る. $760^{\circ} \mathrm{C}$ で再びや」收縮を始め $860^{\circ} \mathrm{C}$ より曲線は 急激に降下しカオリンのみの場合より著しく收縮する。.しかし 980 ○に達すると其收縮は終り其れより $1100^{\circ} \mathrm{C}$ 迄素地は膨脹し次に僅 に收縮した後 $1140^{\circ} \mathrm{C} よ り$ 新たに膨脹が起つて來る.

$620^{\circ} \mathrm{C}$ にて方解石より炭酸瓦斯力發生しカオリンは同時に酸化カ ルシウムと反應する, しかし $880^{\circ} \mathrm{C}$ に於て起る球酸アルミニウム 支び $\boldsymbol{\gamma}-\mathrm{Al}_{2} \mathrm{O}_{3}$ の生成は妨げられる事はない。 $980^{\circ} \mathrm{C}$ に於ける临曲は $\gamma-\mathrm{Al}_{2} \mathrm{O}_{3}$ の非常に劇しい形成であつて此が曲線に現はれるが此現象 は $880^{\circ} \mathrm{C}$ の後の大なる收縮の後始めて起るものである. $980^{\circ} \mathrm{C}$ 以上 では存在する $\mathrm{Al}_{2} \mathrm{O}_{3}$ を喰ひ盡しつ」石灰一䙪土一珠酸籃が形成され

第 12 圖 $70 \%$ チェットリッッカオリン $+30 \%$ 方解石素地の膨脹收縮曲線

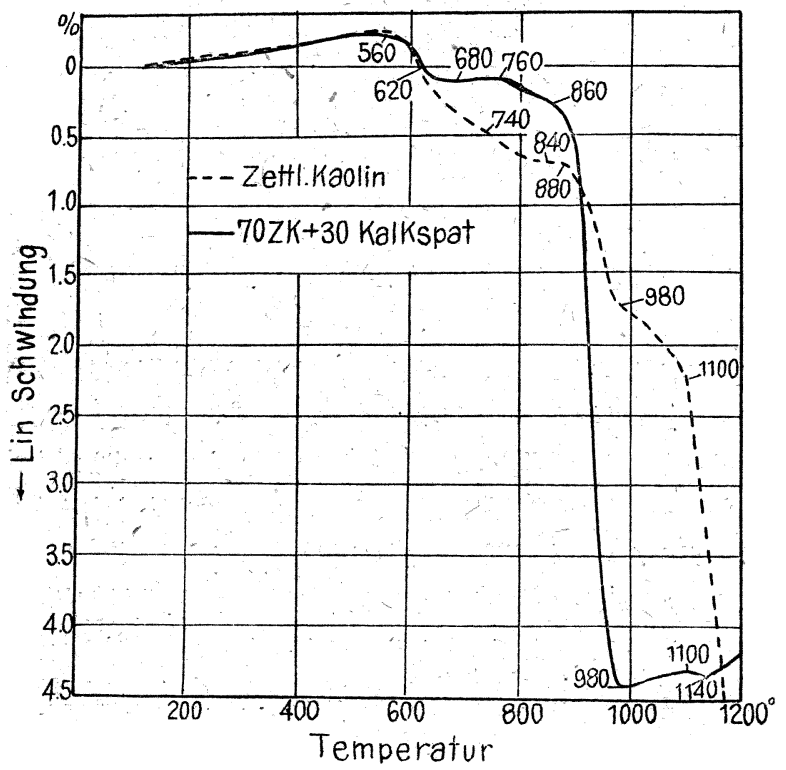

第 13 圖 $70 \%$ チェットリッツカオリン $+30 \%$ マグネサイトの膨脹收縮曲線

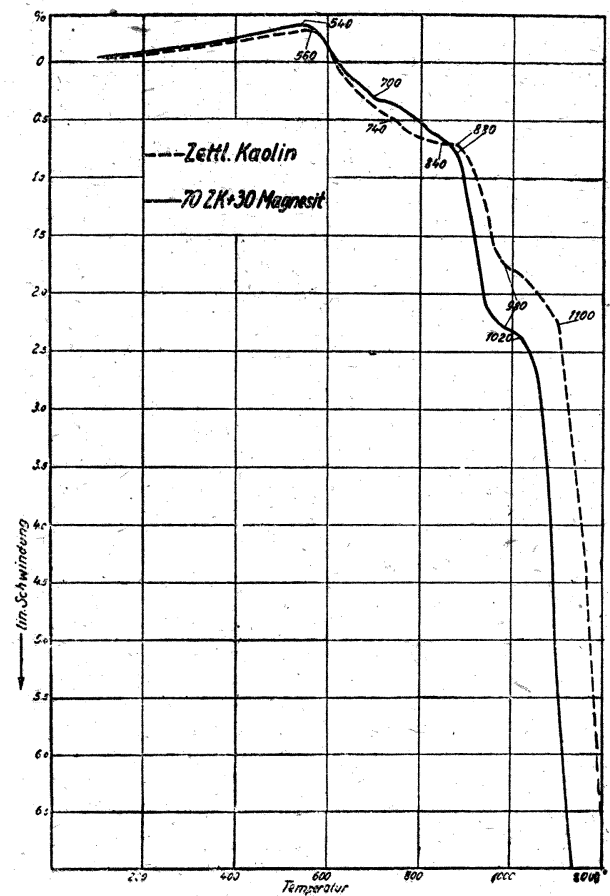

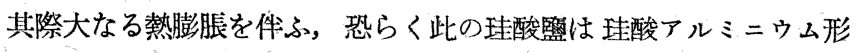
成に對し鐄化劑的役割を呈するものであらら.

次に第 13 圖にはマグネサイト $30 \%$ 加へた時のチェットツッッ カオリンの膨脹收縮を測定したがマグネサイトはカオリンのみの場 合より $540^{\circ} \mathrm{C}$ 迄の熱膨脹を大ならしめる. $700^{\circ} \mathrm{C}$ に於ける曲線の彎 曲は已に生成した $\mathrm{MgO}$ とカオリンの分解生成物之の間に反應が開 始される事を意味してるる, 又 $880^{\circ} \mathrm{C}$ 及び $980^{\circ} \mathrm{C}$ に於ける彎曲點 が示す樣に珠酸アルミニウム及び $\gamma-\mathrm{Al}_{2} \mathrm{O}_{3}$ の生成は $\mathrm{M}_{8} \mathrm{O}$ のため に妨げられる事がない. $1020^{\circ} \mathrm{C}$ では $\mathrm{MgO}$ の强い熔媒作用を發揮 し $1200^{\circ} \mathrm{C}$ に於ける此素地の收縮は $9.6 \%$ にも達する.

滑石はマグネサイト之は反對にカオリンに對し約 $1200^{\circ} \mathrm{C}$ 迄は反 應し難い(第 14 圖)， $540^{\circ}-880^{\circ} \mathrm{C}$ 間では滑石は全く不活性な脱粘 劑として作用する. $880^{\circ} \sim 960^{\circ} \mathrm{C}$ 間の劇しい收縮は滑不が他の成分 と反應するのでなく滑不の分解によるものである. $980^{\circ} \mathrm{C}$ にてカオ リンより $\gamma-\mathrm{AJ}_{2} \mathrm{O}_{3}$ が劇しく生成した後の比較的高溫に於ても滑石よ り生じた $\mathrm{MgO}$ の融劑的作用は明に起つて居ない: $1060^{\circ} \mathrm{C}$ 以上で初 めて曲線か;屈曲するが此處で恐らく滑石の分解生成物とカォリンと の間に最初の反應が起るのであらら。

第 14 圖 $70 \%$ チェットリッッカオリン+30\% 滑石素地の膨脹收縮曲線

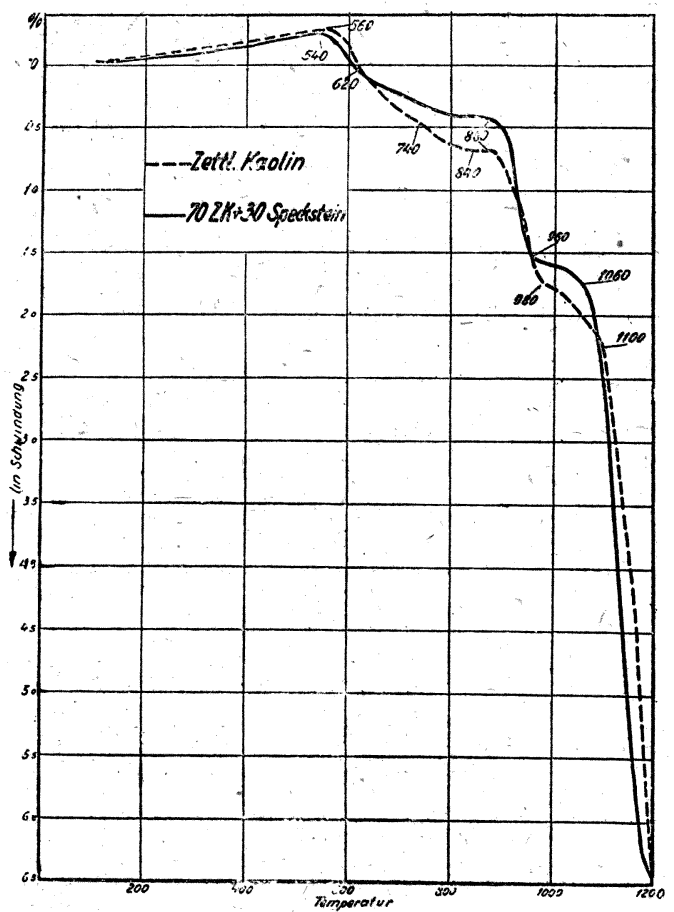

チェットリッッカオリンに對し $30 \%$ の螢不を添加した場合は第 15 圖に示寸如く $540^{\circ} \mathrm{C}$ 以下で脱粘されないカオリンの熱膨脹を非 常に增大せしめる. 郎ち $540^{\circ} \mathrm{C}$ の膨脹は脫粘されないカオリンで $0.29 \%$ なるに對し此素地は $0.53 \%$ でる. 粘土質物より脱水し, 最 初の比較的强い收縮が起つた後 $840^{\circ}$ 及び $880^{\circ} \mathrm{C}$ 迄は弱い收縮が起 る. 珠酸アルミニウム及び $\gamma-\mathrm{Al}_{2} \mathrm{O}_{3}$ が生成し始めるや否や此の二つ の化合物は喰ひ盡され, 只 $980^{\circ} \mathrm{C}$ で $\gamma-\mathrm{Al}_{2} \mathrm{O}_{3}$ の夕が弱く生成され てるるに過ぎない，而して收縮は溫度が上昇するに從つて强く增大 し $1040^{\circ} \mathrm{C}$ で巳にカオリンが $1200 \mathrm{C}$ で示した值 $6.5 \%$ に達する. 此迄述べて來たところの一定溫度で變化點及び屈曲點を有するす べての曲線形より結果を求むれば次の樣な事が知り得られる, 郎ち 已に他の頁にて說明した樣に，カオリン及び粘土は特徵ある膨脹收 縮曲線を示す故に此曲線より窑業製品の燒成時に於ける變化が結論 
第 15 圖 70\%チェットリッツカオリ ン $+30 \%$ 䖝石の膨脹收縮曲線

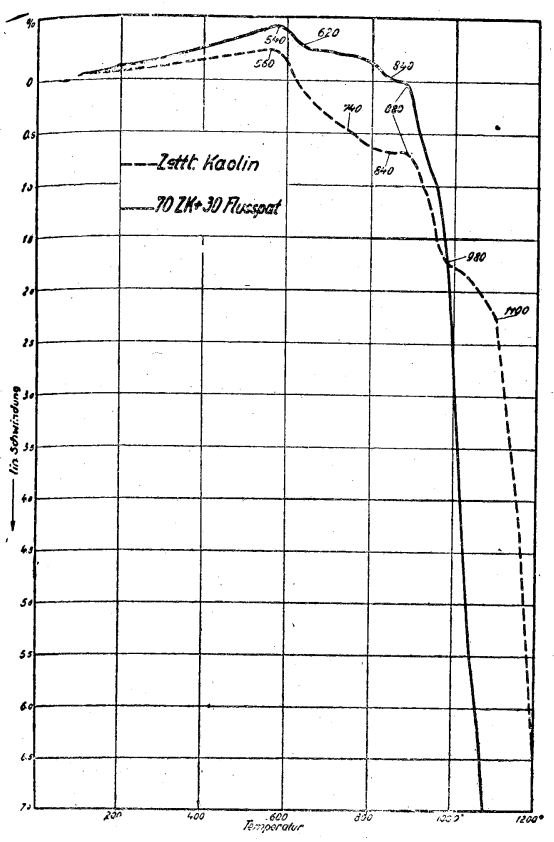

し得られるのみな らず佮又カオリン と種々の脫粘添加 物を有する筀業素 地に就いても燒成 過程を明にし得 る. 脫粘劑及び融 劑の作用は明に曲 線に現はれるもの である。

若しカオリンと 2 種の異なる脫粘 劑とは適當な重量 比に調合する時は 已に我々によく知 られたところの二 成分素地の收縮曲 線形が多少明膫に 現はれる。

50分 (重量) の

チェットリッッカ

オリン, 42 分砂; 3 分長不及び 5 分の方解不より成る混合陶器素 地の膨脹收縮曲線は第 16 圖に見る如く $590^{\circ}, 880^{\circ}, 980^{\circ}$ 交び 1160 ${ }^{\circ} \mathrm{C}$ にて特徽安る曲線點を示し更に $580^{\circ} \mathrm{C}$ 迄は砂による大なる熱膨 脤を，580 $1100^{\circ} \mathrm{C}$ 間では砂及び長石による收縮度減少作用を又 5 \%の方解石による熔媒作用は $760^{\circ} \sim 880^{\circ} \mathrm{C}$ 間で現はれてるる.

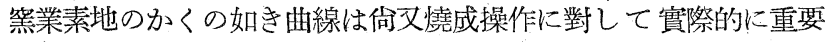
な意義を與へるものである．此の狹い溫度範園で起る强い收縮は燒 成品を告險ならしめる故か子る溫度範圍に於汀る溫度上昇は緩やか にすべきである。例へば此混合陶器に對しては $900^{\circ} \mathrm{C}$ 以上の溫度に 對してはか」る注意が要る事になる。

第 16 圖 混合陶器の膨脹收縮曲線

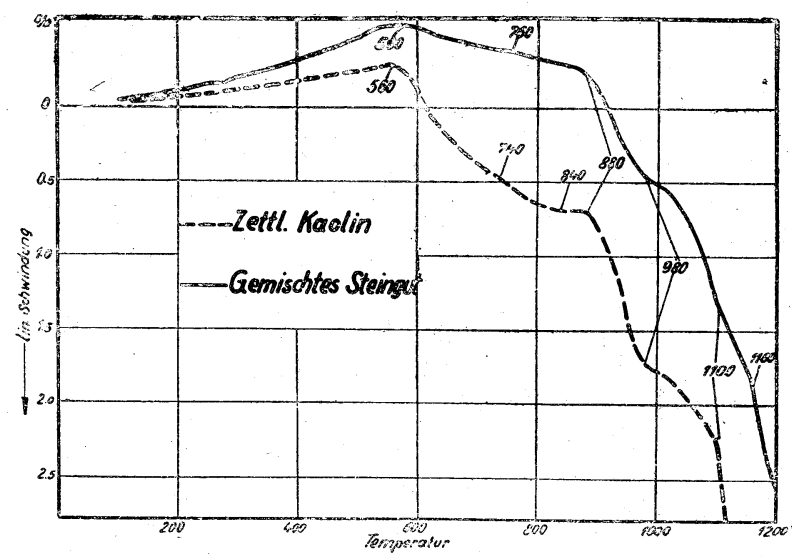

50 分 (重量)のチェットリッッカオリン, 25 分の砂, 20 分の方解 石及び 5 分のマグネサイトより成る石灰陶器素地の膨脹收縮曲線を 見るに (第 17 圖) 其狀態は全く前のチェットリッツカオリンと方解 石より成る混合物が示した過程に支配されてるる.特に $560^{\circ} \sim 900^{\circ} \mathrm{C}$ 間と $960^{\circ} \sim 1200^{\circ} \mathrm{C}$ 間の曲線狀態が類似してるて特徽あるものであ る. 佾又砂による影響特に收縮を減少せしめる影響が明に曲線中に 認められる. 燒成時の危險なる溫度範圍は此では $860^{\circ} \sim 960^{\circ} \mathrm{C}$ 間に 存在寸る.

$560^{\circ} \mathrm{C}$ 迄の磁器の大なる膨脹は砂及び長石によつて起り $560^{\circ}$

第 17 圖 硬質磁器の膨脹收縮曲線

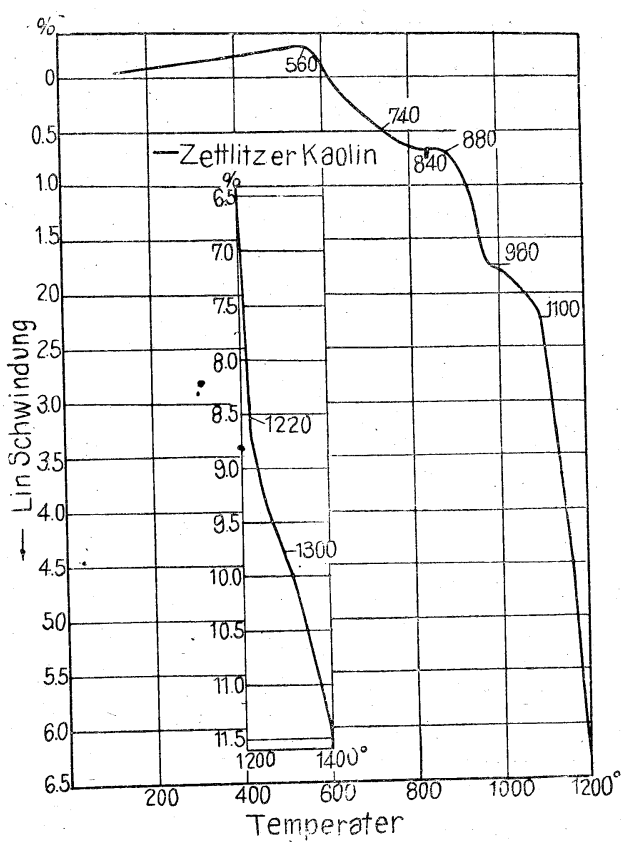

$880^{\circ} \mathrm{C}$ 間の僅な收縮は第一に長不によるものであり又 $60^{\circ} \mathrm{C}$ 以上 $1020^{\circ} \mathrm{C}$ 迄に於ては石英及び長石が共に其收縮を少ならしめる作用が ある. $1020^{\circ} \mathrm{C}$ に於ては長不の融劑作用が收縮曲線中に大つて來るも ので其作用は $1260^{\circ} \mathrm{C}$ に溫度か上昇する迄段々增大寸る。 $1260^{\circ}$ よ り $1380^{\circ} \mathrm{C}$ 迄は更に收縮が大となり最初の $1260^{\circ} \sim 1300^{\circ} \mathrm{C}$ 間の收縮 は $1300^{\circ} \sim 1380^{\circ} \mathrm{C}$ 間の收縮より大である. $13 \div 0^{\circ} \sim 1400^{\circ} \mathrm{C}$ 內で收縮は 非常に減少するから $1380^{\circ} \mathrm{C}$ で收縮は殆ど最高值に達する。此素地

第 18 圖 硬質磁器の膨脹收縮曲線

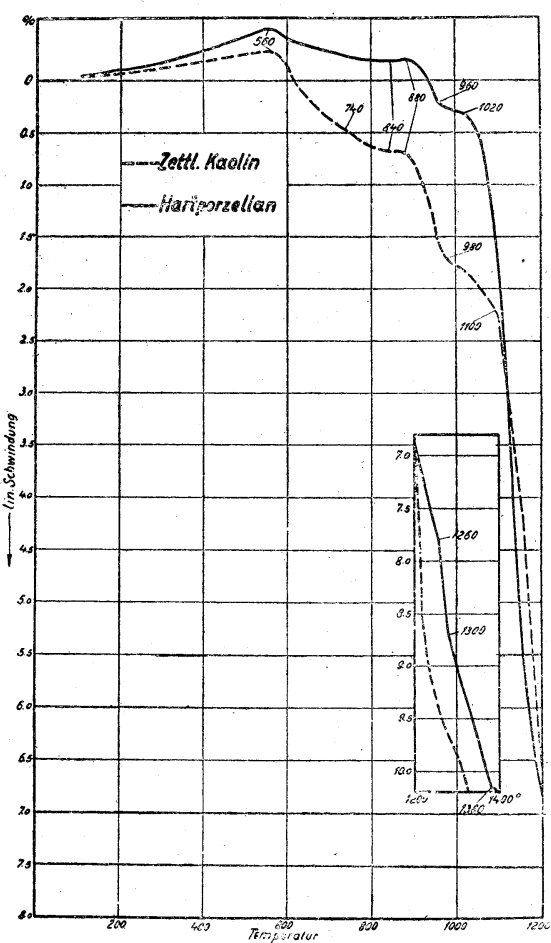

にした.
の强い收縮の溫度 範圍は數百度以上 に達する。

此迄述べて來 た樣な粗雜な實驗 では或は燒成時に 於ける割業素地の 收縮過程及び其意 義を研究する際に 起る色々の疑問を 解決しないか子知 れない，其故に此 を解決するには只 絶えず以上の未燒 成䳐業素地の定ま つた膨脤及び收縮 を出來る丈け科學 的に又は實際的に 利用する事に㫘熟 する事である・測 定結果の詳細なる 發表は留保する事 
$447 \sim 449,465 \sim 468,481 \sim 485,501 \sim 504,517 \sim 521$; bes. S. 447 448; vergl. auch V. Bodin und P. Gaillard, Inst. Cer. Franc. Bull. Nr. 9 (Jan 1937)

2. Z. anorg. Ch. 156 (1931), S. 213 219

3. Vergl, I

4. T. Yoshioka, Journ. Soc. Chem. Ind. Tapan., 39 (1933), Nr. 6, S. $308 \mathrm{~B}$ bis $309 \mathrm{~B}$; T. Yoshioka, T. Horie, J. Karashima, Journ. Soc. Chem. Ind. Japan, 1934, 37, S. 172B
$175 \mathrm{~B}$

5. Journ. Amer. Cer. Soc., 1934, 17, S. 5059; 18 (1935), S. 99 100 .

6. Ann. Phys., 5 Folge, Bd. 4. (1930), Nr. 4. S. $493 \sim 512$

7. Ber. D.K.G. 7 (1936), S. $321 \sim 337$

8. Ber. D.K.G. 15 (1934), S. $2 \sim 14$

(東京工業大學絜業學科)(昭 17. 1.6 受附)

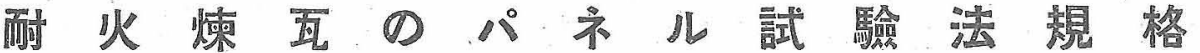

\section{平田 艺郎}

緒 言 本資料は A. S. T. M. on Refractory Materials の

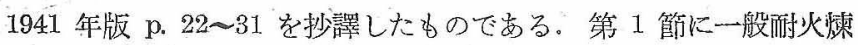
瓦炕對する一般的試驗法 (Standard Method of Panel Test for Resistance to Thermal and Structural Spalling of Refractrory Brick）を述べてあり，第 2 節に於て第 1 節の試驗法を憵用して特 種耐火練瓦のスポーリング試驗法の詳細なる記述が要る。郎ち第 2 節の試驗法は (Standard Method of Panel Test for Resistance to Thermal and Structural Spalling of High Duty Fireclay Brick)である.更に p. 32〜33 には Super Daty Fireclay Brickの

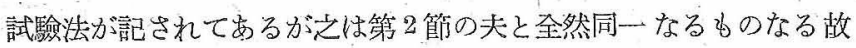
省略する。

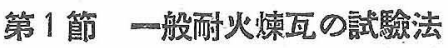

1. 粮 票 (a) 此の試驗法は構造的スポーリングと蓺的スポー リシグとの個及の效果と兩者結合した效果に對する耐火榻瓦の抵抗 力を決定する力法の睦略を示するのである。試驗法は實驗データと 相關聯した或種の操作に對する適應性試驗としてその利用方面を暗 示する操作佟件の充分な類似性を與へるるのと信じられる。

(b) 個々の種類の耐火物に對しては，以下述べる操作と例用される ベき詳略な試騟法は第二節に記述される。

2. 裝 置 試驗法の裝置は次のもの方成立してるる.

(a) パネル楛—パネル枠は第 1 圖と本質的に同一のbのを使用 する。

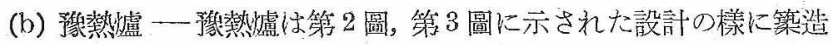
したものを使用する。

(c) スポーリンダ㠠 - スポーリング盧は第 4 圖，第 5 圖，笨6 圖 に示杂た方式で築灒したるのを使用する。

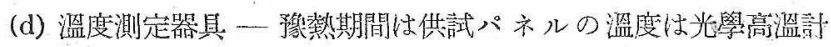
で測定しスポーリング爐の溫度は白金・白金ロデウムの熱電對を 用ひて決定する。

(e) 給氣一一定速度で华冷却單储を通して宾氮を放出する方法 が講ぜられる。

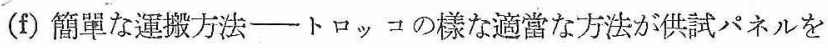
運搬するのに使用される。

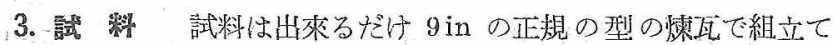
る樣にする，他の大きさの形のもので試驗するときには試料を厚さ $3 \mathrm{in}$ 以上，長さ 9 in 以下，幅 $4 \mathrm{~T} / 2$ in 以下になる樣に切斷与る。
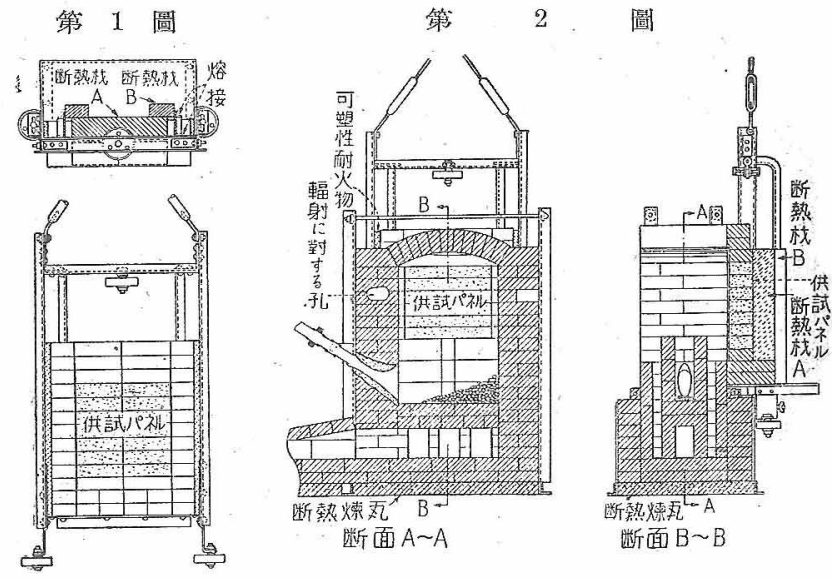

筑 3 圖 パネ几を有する豫熱爐

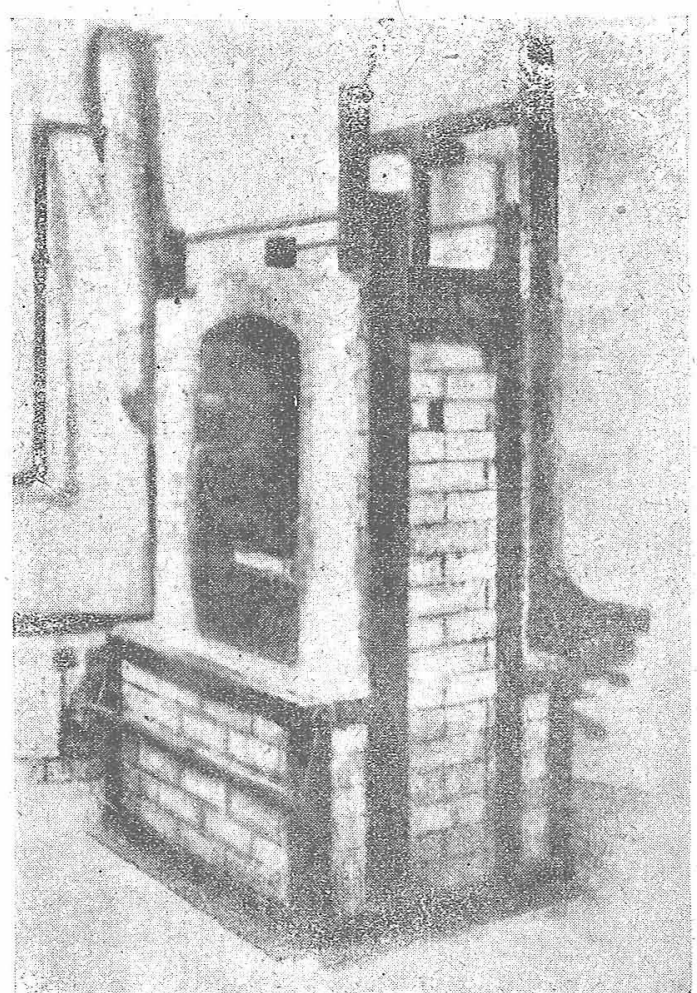

